\title{
Susceptibility of different serovars of Chlamydia trachomatis to inactivation by normal human serum
}

\author{
M F OSBORN, A P JOHNSON, AND D TAYLOR-ROBINSON \\ From the Division of Sexually Transmitted Diseases, MRC Clinical Research Centre, Harrow, Middlesex
}

SUMMARY The ability of a panel of normal human serum samples to inactivate 12 strains of Chlamydia trachomatis, each of a different serovar, was investigated. A wide range of antichlamydial activity was observed, with survival rates of $C$ trachomatis varying from $<1 \%$ in some experiments to $100 \%$ in others. The strain specificity of the anti-chlamydial activity exhibited by individual serum samples was not, however, related to the antigenic cross reactivity between serovars demonstrable by microimmunofluorescence testing, which suggested that type specific antigens were not predominantly involved in the inactivation process.

\section{Introduction}

Chlamydia trachomatis is an important human pathogen, which produces disease in the genital tract, eye, and respiratory tract. ${ }^{1}$ Although chlamydiae are known to infect epithelial cells and often to induce an inflammatory reaction at the site of infection, the pathogenesis of disease produced by such infections is poorly understood. Attempts have been made recently to elucidate the possible role of non-specific host defence mechanisms in the resistance to, and pathogenesis of, chlamydial disease. Yong et al have shown that $C$-trachomatis organisms are killed by polymorphonuclear leucocytes in vitro, ${ }^{2}$ a finding which suggests that the development of an acute inflammatory response by the host may help to eliminate chlamydiae from sites of infection.

Work in this laboratory has shown that another potentially important non-specific host defence mechanism is the ability of normal human serum to inactivate $C$ trachomatis. ${ }^{3}$ Although the serum samples studied had undetectable or low levels of antibody to chlamydiae when tested by microimmunofluorescence, the anti-chlamydial activity required both heat stable and heat labile factors and calcium ions, which suggests the involvement of the classic pathway of complement activation.

In this report we present the results of a study of the specificity of the anti-chlamydial activity of normal human serum samples, which has been

Address for reprints: Mrs M F Osborn, Division of Sexually Transmitted Diseases, MRC Clinical Research Centre, Watford Road, Harrow, Middlesex HA1 3UJ

Accepted for publication 13 December 1984 investigated by assessing the ability of a panel of serum samples to inactivate different serotypes of $C$ trachomatis.

\section{Materials and methods}

\section{CHLAMYDIA TRACHOMATIS}

We used 12 strains of $C$ trachomatis, each belonging to a separate serovar (table I). They were obtained from the Institute of Ophthalmology, London, after passage in eggs, and were subsequently passed several times in McCoy cells treated with cycloheximide ${ }^{4}$ to produce stock pools. These were stored in liquid nitrogen in sucrose phosphate medium (2SP) containing $10 \%$ heat inactivated fetal calf serum. All strains were thawed rapidly and diluted to provide $10-60 \times 10^{3}$ inclusion forming units $/ \mathrm{ml}$.

TABLE I Strains of Chlamydia trachomatis examined for their susceptibility to inactivation by normal human serum

\begin{tabular}{ll}
\hline Strain & Serovar \\
\hline SA-1 & A \\
TW-5 & B \\
UW-1 & C \\
Cal-8 & D \\
DK-20 & E \\
MRC 301 & F \\
10L-238 & G \\
UW-4 & H \\
UW-12 & I \\
UW-36 & U \\
UW-31 & K \\
SA $\mathbf{f}$ & $\mathrm{L}_{2}$ \\
\hline
\end{tabular}

\section{SERUM SAMPLES}

Blood samples were obtained from 13 volunteers on the staff of the Clinical Research Centre, after 
approval had been given by the Ethics Committee. Each blood sample was allowed to clot for one hour at room temperature, and the serum was separated by centrifuging and stored in small volumes at $-70^{\circ} \mathrm{C}$. All the serum samples were screened for the presence of antibody to the chlamydial group antigen using an enzyme linked immunosorbent assay (ELISA) technique. ${ }^{5}$

\section{TEST SYSTEM}

To assess whether $C$ trachomatis organisms were inactivated by serum, $40 \mu \mathrm{l}$ volumes of chlamydial suspension were added to $360 \mu$ l volumes of unheated or heat inactivated (at $56^{\circ} \mathrm{C}$ for 30 minutes) serum, and the mixtures were incubated at $37^{\circ} \mathrm{C}$ for one hour. The numbers of viable chlamydiae in the mixtures were then estimated by titration in McCoy cells treated with cycloheximide. To avoid subjective bias, the cell monolayers were coded before microscopical examination for chlamydial inclusions. Inactivation of chlamydiae was assessed by comparing the number of viable chlamydiae in unheated serum with the number in the homologous heat inactivated serum.

\section{Results}

\section{SUSCEPTIBILITY OF DIFFERENT SEROVARS OF}

\section{TRACHOMATIS TO INACTIVATION BY}

\section{NORMAL HUMAN SERUM}

Antibody was not detected by the ELISA technique in 11 of the 13 human serum samples that were used but two (Nos 2 and 3, table II) had antibody titres of $1 / 4$ and 1/16 respectively. The latter serum was, however, negative for antibody when tested by microimmunofluorescence. ${ }^{6}$

Table II shows the susceptibility of 12 strains of $C$ trachomatis of different serovars to inactivation by

TABLE II Survival of Chlamydia trachomatis in normal human serum

\begin{tabular}{|c|c|c|c|c|c|c|c|c|c|c|c|c|}
\hline \multirow[b]{2}{*}{ Serum No } & \multicolumn{12}{|c|}{ \% Survival* of indicated serovar of C trachomatis } \\
\hline & $A$ & $B$ & $C$ & $D$ & $E$ & $F$ & $G$ & $H$ & $I$ & $J$ & $K$ & $L_{2}$ \\
\hline 1 & $<1$ & 14 & 5 & $<1$ & $<1$ & $<1$ & $<1$ & $<1$ & $<1$ & $<1$ & $<1$ & $<1$ \\
\hline 2 & NT & $<1$ & 8 & $<1$ & $<1$ & $<1$ & $<1$ & $<1$ & $<1$ & 10 & $<1$ & $<1$ \\
\hline 3 & $<1$ & $<1$ & 65 & $<1$ & $<1$ & $<1$ & $<1$ & $<1$ & 33 & $<1$ & $<1$ & 7 \\
\hline 4 & $<1$ & $<1$ & 44 & 5 & 7 & $<1$ & $<1$ & $<1$ & 2 & $i$ & $<1$ & 14 \\
\hline 5 & $\mathrm{NT}$ & NT & 100 & 2 & $<1$ & $<1$ & $<1$ & 4 & 100 & 2 & $<1$ & 64 \\
\hline 6 & $<1$ & 48 & 2 & 75 & 18 & 3 & 3 & 38 & 2 & 2 & $<i$ & $<1$ \\
\hline 7 & $<1$ & 15 & 18 & 20 & 7 & $<1$ & $<1$ & 32 & $<1$ & 2 & $<1$ & $<1$ \\
\hline 8 & 93 & 75 & 100 & $<1$ & $<1$ & $<1$ & $<1$ & $<1$ & 30 & 1 & 19 & 72 \\
\hline 9 & 31 & 75 & 56 & $<1$ & 38 & $<1$ & $<1$ & 59 & 2 & 1 & $<1$ & 60 \\
\hline 10 & 26 & 25 & 59 & 61 & 42 & $<1$ & $<1$ & $<1$ & $<1$ & 1 & $<1$ & $<1$ \\
\hline 11 & NT & NT & 31 & 32 & $<1$ & 50 & $<1$ & 1 & $<1$ & 100 & 51 & 66 \\
\hline 12 & $<1$ & 69 & 62 & 85 & 20 & 1 & 10 & 27 & $<1$ & 65 & 91 & 35 \\
\hline 13 & $<1$ & 58 & 66 & 64 & 50 & 19 & 8 & $<1$ & 58 & 75 & 55 & 28 \\
\hline
\end{tabular}

* Survival of chlamydiae in unheated serum expressed as a percentage of survival in heat inactivated homologous serum. $\mathrm{NT}=$ not tested. the panel of 13 human serum samples. A wide range of susceptibility to inactivation was found, from $<1 \%$ to $100 \%$ survival. Except for the strain of serovar G, of which $<10 \%$ survived with all the serum samples tested, the strains were not uniformly susceptible or resistant to inactivation by the various human serum samples, each exhibiting $\leqslant 2 \%$ survival with at least one serum and $\geqslant 50 \%$ with at least one other. The strains of serovar $\mathrm{B}$ and $\mathrm{C}$ were the most resistant to killing by serum. Thus $\geqslant 50 \%$ of the organisms survived testing with $36 \%$ and $54 \%$ of the serum samples respectively (table III). In contrast, strains of the other serovars showed survival rates of $\geqslant 50 \%$ with none to only $31 \%$ of the serum samples tested.

TABLE III Proportion of human serum samples exhibiting antichlamydial activity against individual chlamydial serovars

\begin{tabular}{llllll}
\hline & \multicolumn{5}{c}{$\begin{array}{l}\text { No (\%) of serum samples producing } \\
\text { indicated level of chlamydial } \\
\text { survival* }\end{array}$} \\
\cline { 3 - 6 } Serovar & $\begin{array}{l}\text { No of serum } \\
\text { samples tested }\end{array}$ & $\leqslant 10 \%$ & $11-49 \%$ & $\geqslant 50 \%$ \\
\hline A & 10 & $7(70)$ & $2(20)$ & $1(10)$ \\
B & 11 & $3(27)$ & $4(36)$ & $4(36)$ \\
C & 13 & $3(23)$ & $3(23)$ & $7(54)$ \\
D & 13 & $7(54)$ & $2(15)$ & $4(31)$ \\
E & 13 & $8(61)$ & $4(31)$ & $1(8)$ \\
F & 13 & $11(85)$ & 1 & $(8)$ & 1 \\
G & 13 & $13(100)$ & $0(0)$ & 0 \\
H & 13 & $9(69)$ & $3(23)$ & 1 \\
I & 13 & $9(8)$ & $2(15)$ & $2(15)$ \\
J & 13 & $9(69)$ & $0(0)$ & $4(31)$ \\
K & 13 & $9(69)$ & 1 & $(8)$ & $3(23)$ \\
L & 13 & $6(46)$ & $3(23)$ & $4(31)$ \\
\hline
\end{tabular}

* Survival of chlamydiae in unheated serum expressed as a percentage of survival in heat inactivated homologous serum.

\section{SPECIFICITY OF ANTI-CHLAMYDIAL ACTIVITY} OF NORMAL HUMAN SERUM

Most of the serum samples tested varied in their ability to inactivate chlamydial strains of different serovars (tables II and IV). Serum samples Nos 1 and 2 showed the greatest degree of anti-chlamydial activity, with $\leqslant 14 \%$ (more usually $1 \%$ ) of the organisms surviving in any particular experiment, irrespective of the serovars tested. The other serum samples, in contrast, showed a wider range of antichlamydial activity, with $<1 \%$ survival being seen with some serovars, but $32-100 \%$ survival being seen with others.

\section{Discussion}

The results presented here confirm our earlier findings that $C$ trachomatis may be susceptible to inactivation by normal human serum and that serum samples from different donors vary in their anti- 
TABLE IV Survival of strains of Chlamydia trachomatis of different serovars in human serum

\begin{tabular}{|c|c|c|c|}
\hline \multirow[b]{2}{*}{ Serum No } & \multicolumn{3}{|c|}{ Serovars giving indicated \% survival* } \\
\hline & $\leqslant 10$ & $11-49$ & $\geqslant 50$ \\
\hline $\begin{array}{l}1 \\
2 * *\end{array}$ & A,C-L 2 & B & \\
\hline 3 & A, B,D-H,J,L, & I & $\mathrm{C}$ \\
\hline 4 & $\mathrm{~A}, \mathrm{~B}, \mathrm{D}-\mathrm{K}$ & $\mathrm{C}, \mathrm{L}_{2}$ & \\
\hline $\begin{array}{l}5^{*} \\
6\end{array}$ & $\begin{array}{l}\text { D-H,J,K } \\
\text { A,C,F,G,I-L } 2\end{array}$ & $\mathrm{~B}, \mathrm{E}, \mathrm{H}$ & ${ }_{\mathrm{D}}^{\mathrm{C}} \mathrm{I}, \mathrm{L}_{2}$ \\
\hline 7 & $\mathrm{~A}, \mathrm{E}-\mathrm{G}, \mathrm{I}, \mathrm{L}_{2}$ & B-D,H & \\
\hline 8 & D-H,J & $\mathrm{I}, \mathrm{K}$ & $\mathrm{A}-\mathrm{C}, \mathrm{L}_{2}$ \\
\hline 9 & $\mathrm{D}, \mathrm{F}, \mathrm{G}, \mathrm{I}-\mathrm{K}$ & $\mathrm{A}, \mathrm{E}$ & $\mathrm{B}, \mathrm{C}, \mathrm{H}, \mathrm{L}_{2}$ \\
\hline 10 & $\mathrm{~F}-\mathrm{I}, \mathrm{K}, \mathrm{L}_{2}$ & $\mathrm{~A}, \mathrm{~B}, \mathrm{E}$ & $\mathrm{C}, \mathrm{D}, \mathrm{J}$ \\
\hline $11^{* * *}$ & $\mathrm{E}, \mathrm{G}-\mathrm{I}$ & C, D & $\mathrm{F}, \mathrm{J}-\mathrm{L}_{2}$ \\
\hline 12 & $\mathrm{~A}, \mathrm{~F}, \mathrm{G}, \mathrm{I}$ & $\mathrm{E}, \mathrm{H}, \mathrm{L}_{2}$ & B-D,f,K \\
\hline 13 & $\mathrm{~A}, \mathrm{G}, \mathrm{H}$ & $\mathrm{F}, \mathrm{L}_{2}$ & B-E,I-K \\
\hline
\end{tabular}

* Survival of chlamydiae in unheated serum expressed as a percentage of survival in heat inactivated homologous serum.

** serovar A not tested.

*** serovars A and B not tested.

chlamydial activity. ${ }^{3}$ The specificity of the antichlamydial activity exhibited by individual serum samples did not, however, appear to be related to the serological cross reactivity known to exist between the various chlamydial serovars. ${ }^{7}$ In other words, individual serum samples did not tend to inactivate preferentially serovars that are antigenically related, such as those of the BDEL or CJ complexes.

The earlier observation that serum mediated inactivation of $C$ trachomatis involves both heat stable and heat labile serum factors and divalent cations, ${ }^{3}$ strongly indicates involvement of the classic pathway of complement activation. Newhall et al have shown that serum samples from people at low risk of chlamydial infection (such as cloistered nuns, or children), which are generally negative for antibody to chlamydiae by the microimmunofluorescence test, contain antibody to the major outer membrane protein (MOMP) and a 29 kilodalton polypeptide of serovar $L_{2}$ when tested by western blotting. ${ }^{8}$ Both these antigens are expressed on the surface of chlamydial elementary bodies as shown by surface radiolabelling, ${ }^{9}$ and are thus potential targets for antibody and complement. In the study reported by Newhall et al, the intensity of the reaction of antibodies in different serum samples with these antigens, as shown in the autoradiograms, was different, which indicated variations in antibody levels. ${ }^{8}$ The ability of serum to inactivate different serovars of $C$ trachomatis observed in the present study may, therefore, be related to the levels of antibody directed against the MOMP and 29 kilodalton surface polypeptides of the various organisms. Studies to test this hypothesis are currently in progress.

We thank Roger Evans for performing the ELISA and Dr Brenda Thomas for examining serum samples by microimmunofluorescence.

\section{References}

1. Taylor-Robinson D, Thomas BJ. The role of Chlamydia trachomatis in genital tract and associated diseases. $J$ Clin Pathol 1980; 33:205-33.

2. Yong EC, Klebanoff SJ, Kuo C-C. Toxic effect of human polymorphonuclear leukocytes on Chlamydia trachomatis. Infect Immun 1982;37:422-6.

3. Johnson AP, Osborn MF, Rowntree S, Thomas BJ, TaylorRobinson D. A study of inactivation of Chlamydia trachomatis by normal human serum. British Journal of Venereal Diseases 1983;59:369-72.

4. Thomas BJ, Evans RT, Hutchinson GR, Taylor-Robinson D. Early detection of chlamydial inclusions combining the use of cycloheximide-treated McCoy cells and immunofluorescence staining. J Clin Microbiol 1977;6:285-92.

5. Evans RT, Taylor-Robinson D. Development and evaluation of an enzyme-linked immunosorbent assay (ELISA), using chlamydial group antigen to detect antibodies to Chlamydia trachomatis. J Clin Pathol 1982;35: 1122-8.

6. Thomas BJ, Reeve P, Oriel JD. Simplified serological test for antibodies to Chlamydia trachomatis. J Clin Microbiol 1982;4: 6-10.

7. Grayston JT, Wang S-P. New knowledge of chlamydiae and the diseases they cause. $J$ Infect Dis 1975; 132:87-105.

8. Newhall WJ, Batteiger B, Jones RB. Analysis of the human serological response to proteins of Chlamydia trachomatis. Infect Immun 1982; 38: 1181-9.

9. Salari SH, Ward ME. Polypeptide composition of Chlamydia trachomatis. J Gen Microbiol 1981; 123: 197-207. 